
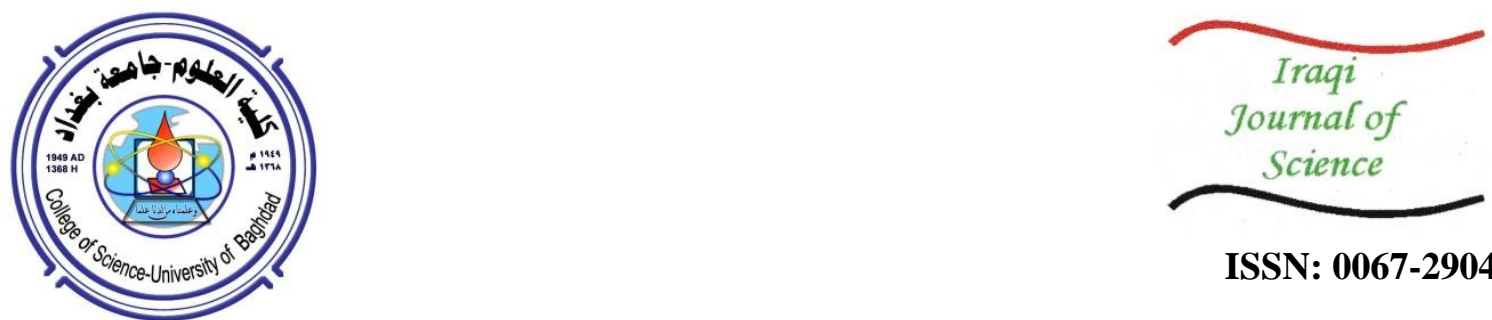

ISSN: 0067-2904

\title{
Effects of Some Cyanophyta Along with the Reduced Levels of Chemical Fertilizers on the Growth and Yield of Wheat
}

\author{
Sanaa, J. Burjus* ${ }^{1}$, Ibrahim S. Alsaadawi ${ }^{1}$, Francis O. Janno ${ }^{2}$ \\ ${ }^{1}$ Department of Biology, College of Science, University of Baghdad, Baghdad, Iraq \\ ${ }^{2}$ State Board of Agricultural Researches, Ministry of Agriculture, Baghdad, Iraq.
}

$$
\text { Received: 26/11/2019 Accepted: 21/1/2020 }
$$

\begin{abstract}
The present work was conducted in the fields of Al-Sewarah and Kurkok stations which belong to the State Board of Agricultural Researches, Ministry of Agriculture, Iraq during the growing season of 2018. The goal of the study was to test the effects of the application of cyanobacteria (Anabaena circinalis and Nostoc commune) alone or in combination with reducing the dose of chemical fertilizers (CFs), which consisted of diammonium phosphate (DAP) and urea (46\% nitrogen), on growth, yield and yield components of wheat cv. IPA99. Application of 50\% and $100 \%$ of $\mathrm{CFs}$ without cyanobacteria as well as control (without cyanobacteria and CFs) were also included in this study for comparison.

The results indicated that the use of wheat grains coated with compost amended with cyanobacteria, grains coated with compost, and foliar spray with cyanobacteria did not change yield, yield components and most of growth parameters tested in both stations. However, application of 50\% CFs along with the treatments that included either the coating of grains with compost amended with cyanobacteria or the foliar spray with cyanobacteria extract resulted in grains yield, yield components, biological yield, harvest index, and test growth parameters similar to those achieved by the recommended dose of CFs. This study suggests that this approach can be applied to reduce the input of chemical fertilizers into the field and thereby reducing the cost and pollution of agroecosystem.
\end{abstract}

Keywords: wheat, cyanobacteria, biofertilizers, foliar, compost.

\section{تأثير الطحالب الخضراء المزرقة مع جرعه مختزلة من سمادي الاب واليوريا في نمو وحاصل الحنطة}

$$
\begin{aligned}
& \text { سناء جميل برجس" ، ابراهيم شعبان السعداوي } 1 \text { ، فرنسيس اوراها جنو2 }
\end{aligned}
$$

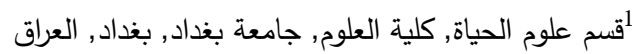

$$
\begin{aligned}
& \text { 22 }
\end{aligned}
$$

*Email: sanaalani_67@yahoo.com. 


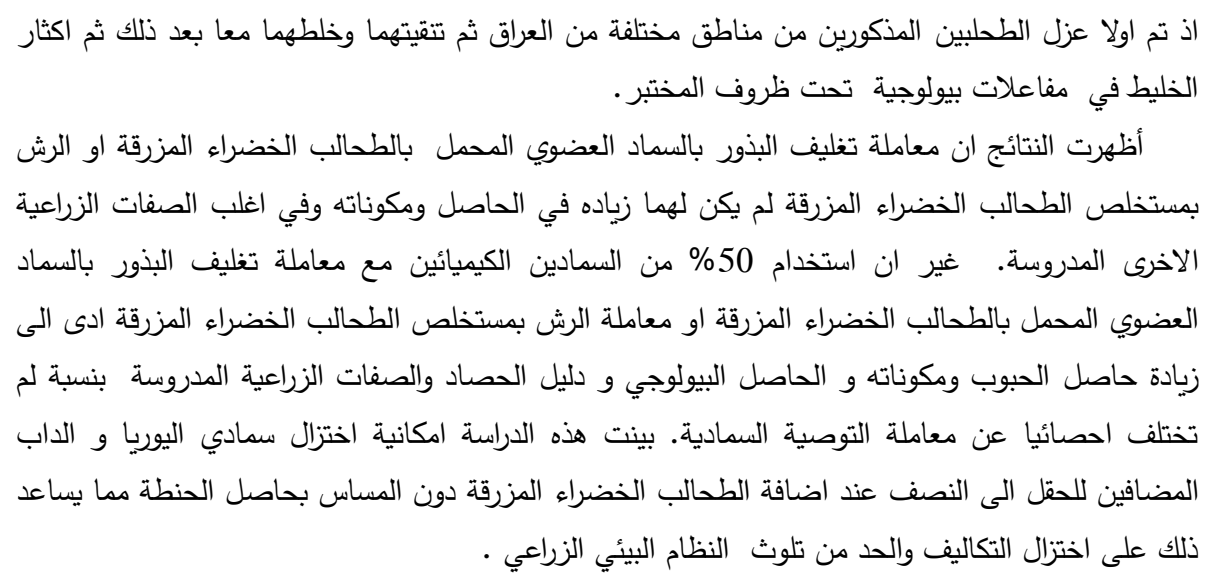

\section{Introduction}

Agricultural fertilizers are essential to enhance proper growth and yield of crops. Most of the agriculture sectors are heavily dependent on inorganic chemical fertilizers. The overdependence and irrational use of chemical fertilizers has led to many associated problems. The growing public awareness in recent past about quality of life has led to concentrate the efforts on searching for alternative agricultural approaches to reduce the input of chemical fertilizers in agroecocystems [1]. The utilization of beneficial microbes as biofertilizers has become a major interest in industrial agriculture for their potential role in food safety and sustainable crop production [2]. Cyanobacteria as biofertilizers is significantly capable of fixing atmospheric nitrogen [3], improving soil fertility and crop productivity, decreasing the pollution of the agricultural environment and enhancing the quality of the produced food [4]. Additional roles of cyanobacteria were reported to include the excretion of a number of substances that influence plant growth and development such as auxin [5], gibberellins [6], cytokinins [7], vitamins, polypeptides, and amino acids [8]. The cyanobacteria can be applied to the field by soil drenching [9], spraying as a foliar extract [10] and by compost amended with cyanbacteria culture [11].

Wheat (Triticum aestivum L.) is one of the oldest cereals widely consumed by human being. It is an important crop in Iraq which cultivates in the rain fed regions in the north and the salt affected areas of the southern and central regions of Iraq. The role of cyanobacteria biofertilizers in cereal crops is reported to be beneficial, as they not only reduce the use of chemical fertilizers but also improve the overall health and nutritional status of soil [12]. No published reports exist on using cyanobacteria as biofertilizers for wheat crop in Iraq under the abovementioned diverse environments. Therefore, the present study was conducted to isolate and purify the local isolates of cyanobacteria (Nostoc and Anabaena) determine the best approach to apply them to the wheat field, and comparing the outcomes of applying them alone or in combination with the reduced dose of chemical fertilizer. The experiments were conducted in the fields of two regions of different environmental conditions in Iraq.

\section{Materials and methods}

Isolation and purification of cyanobacteria

Local cyanobacteria species, Anabaena and Nostoc, were isolated according to Rippka et al. [13] from paddy fields of different sites in Baghdad, Al-Nagaf Al-Ashraf and Al-Diwaniyah during summer of 2018. The isolates were grown in conical flasks containing sterilized blue green algae (BG11) free of nitrogen medium with $\mathrm{pH} 7.2$ or 8.2 and incubated under $16 \mathrm{~h}$ photoperiod (3000 lux) at $28 \pm 2{ }^{\circ} \mathrm{C}$ [14]. The unialgal cultures were purified to obtain axenic culture as described by Pringsheim [15].

\section{Identification of cyanobacteria isolates}

Microscopic examinations were made to identify each of cyanobacteria cultures under low (10x) and high power (40x) objective lens of compound light microscope based on morphological observations, namely thickness of the sheath, and presence or absence of heterocyst, akintes. and gas vacuoles [16] .

\section{Mass cultivation}

Photobioreactor (PBR) is a fermentation bubble column consisting of a circular glass flask of 10 liters volume filled with sterilized liquid BG-11 medium. Cyanobacteria cultures (Anabaena circinalis and Nostoc commune ) were cultivated in a combination of equal portions of fresh weight from each 
algal culture suspension at the stationary phase [9]. The suspensions were mixed together and incubated under $16 \mathrm{~h}$ photoperiod (3000 lux) at $28 \pm 2{ }^{\circ} \mathrm{C}$ with initial $\mathrm{pH}$ values of 7.2 or 8.2 [17]. The cultures were incubated for 2-3 weeks, while being air bubbled by a commercial aquarium pump and maintained until the logarithmic phase achieved [11]. Biomasses of $N$. commune and A. circinalis were collected from several experimental bioreactors. The fresh weights were washed several times with distilled water to remove impurities, crushed, and the resulting salt crystals were used in subsequent experiments [18]. The growth of cyanobacteria was determined by measuring the biomass concentrations in the cultures through the cell dry weight, according to an initial rate of 0.1 to a maximum rate of $1 \mathrm{~g} / \mathrm{L}$, as described by Vonshak et al. [19].

\section{Preparation of cyanobacteria extract}

Cyanobacteria mixtures were harvested by centrifugation at 2,000×g for $10 \mathrm{~min}$. Purified cell pellet was extracted by distilled water using electrical blender at a rate of $5 \mathrm{~g} / 500 \mathrm{ml}(1 \%)$ [20]. The obtained natural extract of cyanobacteria was used as a foliar extract [10].

\section{Incubation of cyanobacteria with compost}

Compost (palm fronds) with typical chemical and physical properties was used as an incubation medium. Ten $\mathrm{ml}$ of mixed culture (A. circinalis and $N$. commune) was added to $100 \mathrm{mg}$ of compost and moisturized with $50 \mathrm{ml}$ distilled water. The culture was then incubated for 30 days and the activity of cyanobacteria was then examined $[11,21]$.

\section{Field study}

\section{Site selection}

The proposed filed study was conducted in two research stations, Al-Sewarah and Kurkok stations, which belong to the State Board of Agricultural Researches, Ministry of Agriculture, Iraq, during the growing season of 2018. Some of the physical and chemical properties of soil of the two stations are listed in Table-1. All tests were conducted in the Soil Testing Laboratory of the State Board of Agricultural Researches. Soil samples from both stations were air-dried and used to determine soil reaction $(\mathrm{pH})$, according to the method of Van Reeuwijk [22], and electric conductivity (EC), following Rhoads and Polemic's method [23]. Soil texture was determined by the hydrometric method as described by Day [24] while the organic matter was determined as stated by Walkley [25]. Bicarbonate, magnesium and calcium concentrations were measured according to Jackson [26]. Carbonate level was determined as reported by Hess [27] while that of sodium was tested as described earlier [28]. Total nitrogen was analyzed using the Kjeldahl's method [29], while phosphorus determination was carried out using Olsen's method [30] and the estimation of potassium was performed according to the procedure reported by Black [31].

Table 1-Some physical and chemical properties of the surface soils from Al-Swearah and Kurkok stations prior to treatments

\begin{tabular}{|c|c|c|}
\hline \multirow{2}{*}{ Parameters } & \multicolumn{2}{|c|}{ Values* } \\
\hline & Al-Sewarah station & Kurkok station \\
\hline $\mathrm{pH}$ & 8.0 & 7.5 \\
\hline E.C. $\mathrm{dS} \mathrm{m}^{-1}$ & 2.6 & 3.2 \\
\hline $\mathrm{Ca} \mathrm{Meq} / \mathrm{l}$ & 27.5 & 27.5 \\
\hline $\mathrm{Mg} \mathrm{Meq} / \mathrm{l}$ & 10.0 & 7.5 \\
\hline $\mathrm{Na} \mathrm{Meq} / \mathrm{l}$ & 5.5 & 16.3 \\
\hline $\mathrm{Cl} \mathrm{Meq/l}$ & 5.0 & 7.5 \\
\hline $\mathrm{Co}_{3} \mathrm{Meq} / \mathrm{l}$ & 0.0 & 0.0 \\
\hline $\mathrm{Hco}_{3} \mathrm{Meq} / \mathrm{l}$ & 2.0 & 1.0 \\
\hline $\mathrm{So}_{4} \mathrm{Meq} / \mathrm{l}$ & 5.7 & 30.9 \\
\hline $\mathrm{N}$ ppm & 28.0 & 21.0 \\
\hline $\mathrm{P}$ ppm & 20.0 & 10.0 \\
\hline $\mathrm{K} \mathrm{ppm}$ & 198.0 & 157.0 \\
\hline O.M. \% & 0.87 & 0.57 \\
\hline$\%$ Sand & 24.4 & 58.0 \\
\hline$\%$ Silt & 37.2 & 36.8 \\
\hline$\%$ Clay & 38.4 & 5.2 \\
\hline Texture & Clay loam soil & Sandy loam soil \\
\hline
\end{tabular}

* Each value is an average of three replicates. 


\section{Implementation of experiments}

The fields of both stations were tilled in December 2018 using a disc plough and each field was divided into 12 plots, each measured $2 \times 3 \mathrm{~m}^{2}$. Wheat grains of $\mathrm{cv}$. (IPA 99) were inoculated with two applications of cyanobacteria mixture either by grains coating with compost amended with cyanobacteria mixture [11], or by foliar spraying [10], and sown in rows at $120 \mathrm{~kg} / \mathrm{ha}^{-1}$ with a distance of $20 \mathrm{~cm}$ between rows. The experiments were conducted in randomized complete block design (RCBD) with three experimental replicates.

The experiments consisted of the following treatments:

1- Control (without cyanobacteria and fertilizers).

2- $50 \%$ CFs (half dose).

3- $100 \%$ CFs (full dose).

4- Grains coating with compost amended with Anabaena circinalis and Nostoc commune mixture (A and $\mathrm{N}$ ).

5- Grains coating with compost amended with Anabaena circinalis and Nostoc commune mixture (A and $\mathrm{N}$ ) and $50 \% \mathrm{CFs}$.

6- Grains coating with compost amended with Anabaena circinalis and Nostoc commune mixture (A and $\mathrm{N}$ ) and $100 \%$ CFs.

7- Grains coating with compost.

8- Grains coating with compost and 50\% CFs.

9- Grains coating with compost and $100 \%$ CFs.

10- Foliar spraying of cyanobacteria (Anabaena circinalis and Nostoc commune) extract (A and N).

11- Foliar spraying of cyanobacteria (Anabaena circinalis and Nostoc commune) extract (A and N) and $50 \%$ CFs.

12- Foliar spraying of cyanobacteria (Anabaena circinalis and Nostoc commune) extract (A and N) and $100 \% \mathrm{CFs}$.

Urea (46\% Nitrogen) at $260 \mathrm{~kg} / \mathrm{ha}^{-1}$ and diammonium phosphate (DAP) at $200 \mathrm{~kg} / \mathrm{ha}^{-1}$ were applied to their respective plots as recommended by the Iraqi Ministry of Agriculture for wheat crop. Half of the nitrogen and all phosphorus were applied during planting, while the remaining nitrogen was applied into three equal portions at tillering, booting and flowering stages [32]. Wheat crop was irrigated as needed at Al-Sewarah station, while rains were the main source of irrigation at Kurkok station.

Grains of wheat cv. IPA 99 were coated with compost amended with or without cyanobacteria in the presence or absence of 50 and $100 \%$ of the recommended dose of CFs [11]. Foliar spraying of cyanobacteria extract at $1 \%(\mathrm{~W} / \mathrm{V})$ was made at the time of urea application by using a spray pump [33]. Tween-20 at $0.1 \%(\mathrm{~V} / \mathrm{V})$ solution was used to decrease the surface tension [34].

The spray was made on plants, fertilized or not fertilized, with 50 or $100 \%$ CFs. At physiological maturity (159 days after cultivation for Al-Sewarah station and $=146$ days after cultivation for Kurkok station), ten plants were randomly selected from each plot and measured for grains and biological yields, harvest index, flag leaf area, chlorophyll, and spike length,-using standard procedures [35].

\section{Statistical analysis}

The data were subjected to statistical analysis using analysis of variance (ANOVA) by GENSTAT computer software package. Differences among treatment averages were compared using Least Significant Difference (LSD) at 0.05 probability level [36].

\section{Results and Discussion}

Our study results indicated that cyanobacteria isolates mixture (Nostoc and Anabaena) ( Figure- 1), cultured in the experiment bioreactors, produced higher fresh biomass at values of $13.2 \mathrm{~g} / \mathrm{l}$ to free sodium nitrate concentrations after 28 days of incubation. The combination of the two cyanobacteria species is believed to significantly increase the germination percentage, stimulate the growth parameters including photosynthetic pigment, and decrease the need for the usage of the mineral form of nitrogen fertilizer [9]. Moisturized compost amended with cyanobacteria significantly affected all test parameters, except salinity which was decreased by $24 \%$ over control, while $\mathrm{N}$ and $\mathrm{P}$ were increased by 38.6 and $14.2 \%$, respectively, over control (Table-2). No attempt was carried out to explore the reasons of such differences; however, previous investigations indicated that the addition of cyanobacteria to compost enhanced the microbial activity and resulted in the excretion of many substances (growth promoting regulators, vitamins, amino acids, polypeptides, antibacterial agents, 
and polymers, especially exopolysaccharides) which induced the growth of other microorganisms [11, 37].

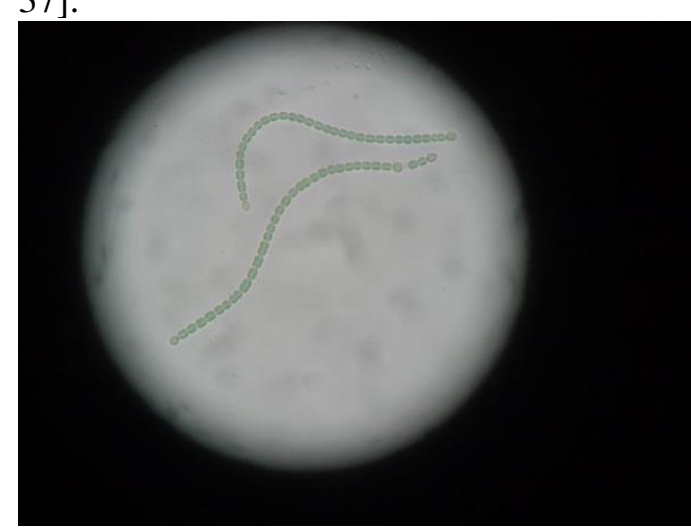

Anabaena circinalis

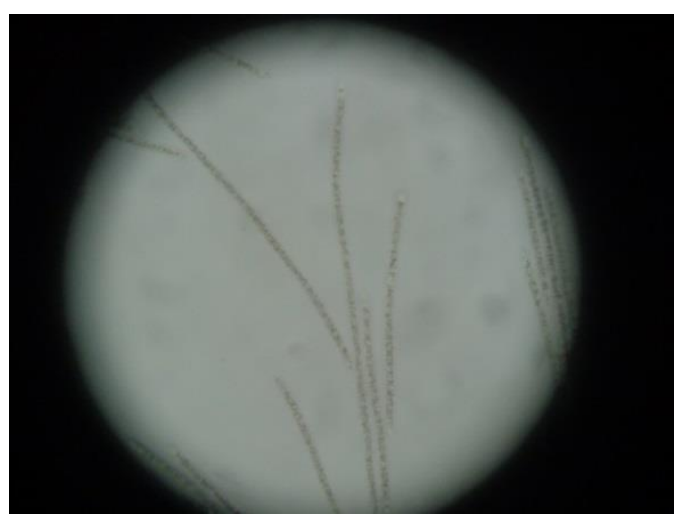

Nostoc commune

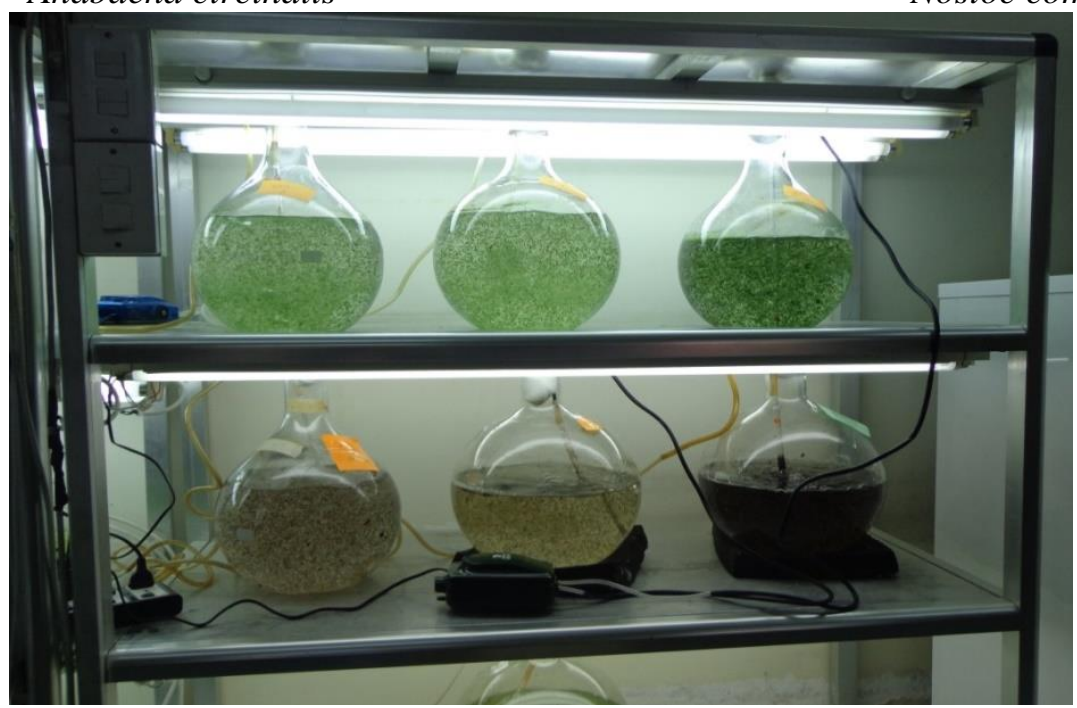

Figure 1-Cultivation of cyanobacteria isolates in bioreactors

It is noteworthy to mention that although the concentrations of nitrogen and phosphorus were increased by the addition of cyanobacteria, the amount added to the medium was far below the concentration required by the plant. Thus the compost can be considered as an inert source of fertilizer.

Table 2 -Biochemical characteristics of compost used in the experiments.

\begin{tabular}{|c|c|c|c|c|}
\hline \multirow{2}{*}{ Treatments } & \multicolumn{4}{|c|}{ Parameters* } \\
\cline { 2 - 5 } & $\mathrm{pH}$ & $\begin{array}{c}\mathrm{EC} \\
\mathrm{dS} \mathrm{m}\end{array}$ & $\begin{array}{c}\mathrm{N} \\
\mathrm{ppm}\end{array}$ & $\begin{array}{c}\mathrm{P} \\
\mathrm{ppm}\end{array}$ \\
\hline Control (compost without addition) & 6.5 & 6.7 & 232 & 121.0 \\
\hline Compost amended with cyanobacteria mixture & 6.6 & 5.1 & 378 & 141.0 \\
\hline LSD $\leq 0.05$ & 0.3 & 0.3 & 46.8 & 9.0 \\
\hline
\end{tabular}

*Each value is an average of three replicates

\section{Effects of cyanobacteria combined with reduced dose of CFs}

All treatments significantly averted grains, yield and harvest index of wheat, with the exception of grains coated with compost amended with cyanobacteria, grains coated with compost, and foliar spraying with cyanobacteria at Al- Sewarah station (Table-3). However, the application of 50\% CFs along with the treatments of grains coating with compost amended with cyanobacteria or foliar with cyanobacteria extract provided grains yield, biological yield and harvest index similar to those achieved by the recommended dose of CFs. 
Table 3-Effects of Anabaena circcinalis and Nostoc commune (A and N) in combination with CFs on grains, biological yields, and harvest index of wheat at Al-Sewarah station.

\begin{tabular}{|c|c|c|c|}
\hline Treatments* & $\begin{array}{c}\text { Grains } \\
\text { Yield } \\
(\mathrm{t} / \mathrm{ha})\end{array}$ & $\begin{array}{c}\text { Biological } \\
\text { Yield } \\
\text { (t / ha) }\end{array}$ & $\begin{array}{c}\text { Harvest } \\
\text { index } \\
(\%)\end{array}$ \\
\hline Control & 2.8 & 10.1 & 28 \\
\hline $50 \% \mathrm{CFs}$ & 4.7 & 12.9 & 34 \\
\hline $100 \% \mathrm{CFs}$ & 5.7 & 15.1 & 38 \\
\hline Grains coating with compost amended with (A and N) & 3.0 & 11.0 & 26 \\
\hline $\begin{array}{l}\text { Grains coating with compost amended with (A and N) and } \\
50 \% \mathrm{CFs}\end{array}$ & 6.1 & 15.4 & 39 \\
\hline $\begin{array}{l}\text { Grains coating with compost amended with (A and N) and 100\% } \\
\text { CFs }\end{array}$ & 5.8 & 15.0 & 39 \\
\hline Grains coating with compost & 2.7 & 9.8 & 28 \\
\hline Grains coating with compost and $50 \%$ CFs & 4.9 & 12.8 & 35 \\
\hline Grains coating with compost and $100 \%$ CFs & 6.1 & 15.7 & 39 \\
\hline Foliar application of cyanobacteria $(\mathrm{A}$ and $\mathrm{N})$ extract & 3.0 & 10.4 & 29 \\
\hline Foliar application of cyanobacteria $(\mathrm{A}$ and $\mathrm{N})$ extract $+50 \% \mathrm{CFs}$ & 6.2 & 16.0 & 40 \\
\hline $\begin{array}{l}\text { Foliar application of cyanobacteria (A and N) extract }+100 \% \\
\text { CFs }\end{array}$ & 6.0 & 16.0 & 38 \\
\hline LSD $\leq 0.05$ & 0.9 & 1.9 & 2.6 \\
\hline
\end{tabular}

* Average of three replicates.

At Kurkok station, lower values of grains and biological yields of wheat were observed due to the differences in the amount of irrigation water, soil texture, and other factors. Yet, the trend of the effects of the tested treatments on growth and yield parameters remained almost the same (Table-4). Treatments that included grains coating with compost amended with cyanobacteria, grains coating with compost, and cyanobacteria extract applied as a foliar, did not have significant differences from control in all parameters of yield components. Also, combined application of 50\% CFs and grains coating with compost amended with cyanobacteria or cyanobacteria extract as a foliar have resulted in grains, biological yields, and harvest index values similar to those achieved by sole application of the recommended rate of CFs.

Table 4-Effects of Anabaena circcinalis and Nostoc commune (A and N) alone and in combination with CFs on grains and biological yields of wheat at Kurkok station.

\begin{tabular}{|c|c|c|c|}
\hline Treatments* & $\begin{array}{c}\text { Grains } \\
\text { Yield } \\
(\mathrm{t} / \mathrm{ha})\end{array}$ & $\begin{array}{c}\text { Biological } \\
\text { Yield } \\
(\mathrm{t} / \mathrm{ha})\end{array}$ & $\begin{array}{c}\text { Harvest } \\
\text { index } \\
(\%)\end{array}$ \\
\hline Control & 2.13 & 9.44 & 23 \\
\hline 50\% CFs & 3.67 & 12.81 & 29 \\
\hline 100\% CFs & 4.77 & 14.44 & 33 \\
\hline Grains coating with compost amended with (A and N) & 2.23 & 10.64 & 21 \\
\hline $\begin{array}{c}\text { Grains coating with compost amended with (A and N) and 50\% } \\
\text { CFs }\end{array}$ & 4.80 & 14.01 & 34 \\
\hline $\begin{array}{c}\text { Grains coating with compost amended with (A and N) and } \\
\text { 100\% CFs }\end{array}$ & 4.63 & 13.84 & 34 \\
\hline Grains coating with compost & 2.10 & 9.24 & 23 \\
\hline Grains coating with compost and 50\% CFs & 3.77 & 12.43 & 30 \\
\hline Grains coating with compost and 100\% CFs & 4.53 & 13.33 & 34 \\
\hline $\begin{array}{c}\text { Foliar application of cyanobacteria (A and N) extract and 50\% } \\
\text { CFs }\end{array}$ & 2.20 & 9.20 & 24 \\
\hline $\begin{array}{c}\text { Foliar application of cyanobacteria (A and N) extract and } \\
\text { 100\% CFs }\end{array}$ & 4.17 & 13.54 & 35 \\
\hline LSD $\leq 0.05$ & 0.38 & 1.66 & 2.5 \\
\hline
\end{tabular}


* Average of three replicates

The results presented in Tables- 3 and 4 show that the application of cyanobacteria with compost or as a foliar in the absence of 50\% CFs did not have any significant effects on grains, biological yields, and harvest index of wheat. However, once this amount of fertilizer was added, a remarkable increase in grains, biological yield and harvest index over control and over sole application of $50 \% \mathrm{CFs}$ treatments was obtained. This suggests that this amount of fertilizer did not only improve the nutritional status of the plant but also provided growth conditions with nitrogen and phosphate which are essential for the growth and propagation of cyanobacteria [38].

The increased harvest index value suggests that the plant may be able to transfer and allocate more dry matter towards the grains, and thereby grains crop yield is enhanced [39].

\section{Effects of cyanobacteria combined with reduced CFs}

The treatments that included grains coating with compost amended with cyanobacteriagrains coating with compost, and cyanobacteria extract applied as a foliar did not show significant differences in comparison to the control in all yield component parameters tested. An exception was the number of spikes/plot which was recorded to be higher in foliar application of cyanobacteria extract than in control in Al-Sewarah station (Table- 5). However, a highly significant increase in the tested growth parameters was achieved following the application of 50\% of CFs combined with compost amended with cyanobacteria or with cyanobacteria extract . Remarkably, the increase in yield components in the aforementioned treatments was statistically similar to that of the label rate of CFs.

Table 5-Effects of Anabaena circinalis and Nostoc commune (A and $\mathrm{N}$ ) alone and in combination with reduced CFs on yield components of wheat at Al-Sewarah station.

\begin{tabular}{|c|c|c|c|}
\hline Treatments* & $\begin{array}{c}\text { Number } \\
\text { of spikes } \\
\text { /plot* }\end{array}$ & $\begin{array}{c}\text { Number } \\
\text { of grains } \\
\text { /spike** }\end{array}$ & $\begin{array}{c}\text { Weight of } \\
1000 \\
\text { grains* (g) }\end{array}$ \\
\hline Control & 204 & 40 & 29.1 \\
\hline 100\% CFs & 345 & 48 & 31.4 \\
\hline $\begin{array}{c}\text { Grains coating with compost amended with (A and N) } \\
\text { Grains coating with compost amended with (A and N) and } \\
\text { 50\% CFs }\end{array}$ & 439 & 56 & 33.3 \\
\hline $\begin{array}{c}\text { Grains coating with compost amended with (A and N) and } \\
\text { 100\% CFs }\end{array}$ & 425 & 57 & 31.8 \\
\hline Grains coating with compost & 2303 & 53 & 33.7 \\
\hline Grains coating with compost and 50\% CFs & 353 & 47 & 31.4 \\
\hline Grains coating with compost and 100\% CFs & 425 & 54 & 33.0 \\
\hline Foliar application of cyanobacteria (A and N) extract & 271 & 43 & 31.1 \\
\hline $\begin{array}{c}\text { Foliar application of cyanobacteria (A and N) extract and } \\
\text { Fo\% CFs }\end{array}$ & 455 & 54 & 33.5 \\
\hline $\begin{array}{c}\text { 100\% CFs } \\
\text { LSD } \leq 0.05\end{array}$ & 433 & 52 & 32.1 \\
\hline
\end{tabular}

* Average of three replicates. ** Average of ten replicates

At Kurkok station, yield component values were lower than those of Al-Sewarah station, yet, the trend of the effects of the test treatments remained almost consistence across the stations (Table-6). Treatments that included grains coating with compost amended with cyanobacteria, grains coating with compost, and cyanobacteria extract applied as a foliar did not show significant differences than the control in all yield component parameters tested (Table-6). On the other hand, application of 50\% CFs along with compost amended with cyanobacteria or with foliar cyanobacteria extract resulted in similar yield components as those noticed at $100 \% \mathrm{CFs}$. 
Table 6-Effects of Anabaena circcinalis and Nostoc commune (A and N) alone and in combination with CFs on yield components of wheat at Kurkok station.

\begin{tabular}{|c|c|c|c|}
\hline Treatments* & $\begin{array}{c}\text { Number } \\
\text { of spikes } \\
\text { /plot* }\end{array}$ & $\begin{array}{c}\text { Number } \\
\text { of grains } \\
/ \text { spike** }\end{array}$ & $\begin{array}{c}\text { Weight of } \\
1000 \\
\text { grains (g)* }\end{array}$ \\
\hline Control & 198 & 39 & 24.60 \\
\hline 50\% CFS & 303 & 42 & 27.14 \\
\hline 100\% CFS & 377 & 49 & 31.20 \\
\hline Grains coating with compost amended with (A and N) & 211 & 40 & 25.58 \\
\hline Grains coating with compost amended with (A and N) and & 377 & 49 & 31.10 \\
\hline 50\% CFs & 350 & 48 & 30.15 \\
\hline $\begin{array}{c}\text { Grains coating with compost amended with (A and N) and } \\
\text { 100\% CFs }\end{array}$ & 196 & 41 & 25.41 \\
\hline Grains coating with compost & 315 & 43 & 27.64 \\
\hline Grains coating with compost and 50\% CFs & 370 & 49 & 30.11 \\
\hline Grains coating with compost and 100\% CFs & 227 & 41 & 25.88 \\
\hline Foliar application with (A and N) extract & 397 & 50 & 31.90 \\
\hline Foliar application with (A and N) extract and 50\% CFs & 355 & 48 & 31.07 \\
\hline Foliar application with (A and N) extract and 100 CFs & 51 & 2.6 & 1.73 \\
\hline LSD $\leq 0.05$ & & & \\
\hline
\end{tabular}

$*$ Average of three replicates. $* *$ Average of ten replicates

The results in Tables- 5 and 6 revealed that the increase in grains yield was found to be due to the increase in all yield components in both stations. The increased number of spikes, number of grains per spike, and weight of 1000 grains when cyanobacteria was applied with 50\% CFs may be attributed to the prolonged nutrients availability by cyanobacteria through the whole life cycle of wheat, through thus decreasing the leaching of nutrients [40].

\section{Effects of cyanobacteria combined with reduced dose of CFs}

Treatments of grains coating with compost amended with cyanobacteria, grains coating with compost, and cyanobacteria extract applied as a foliar did not show significant differences from the control treatment in all agronomic traits tested. An exception was noticed in chlorophyll content and plant height which were increased by treatments by cyanobacteria extract and grains coating with compost amended with cyanobacteria, respectively (Table-7). However, a highly significant increase in the tested growth parameters was achieved following the application of 50\% of CFs combined with compost amended with cyanobacteria or with cyanobacteria extract. Remarkably, the increase in agronomic traits in the aforementioned treatments was statistically similar to that of the label rate of chemical fertilizers (100\% CFs).

Table 7- Effects of Anabaena circcinalis and Nostoc commune (A and N) alone and in combination with CFs on some agronomic traits of wheat at Al- Sewarah station .

\begin{tabular}{|c|c|c|c|c|}
\hline Treatments* & $\begin{array}{c}\text { Plant } \\
\text { height } \\
\mathrm{cm}\end{array}$ & $\begin{array}{c}\text { Flag } \\
\text { leaf } \\
\text { area } \\
\mathrm{cm}^{2}\end{array}$ & $\begin{array}{c}\text { Chlorophyl } \\
\text { (SPAD } \\
\text { units) }\end{array}$ & $\begin{array}{c}\text { Spike } \\
\text { length } \\
\mathrm{cm}\end{array}$ \\
\hline Control & 68.0 & 34.8 & 38.9 & 9.9 \\
\hline 50\% CFs & 74.2 & 43.3 & 47.3 & 11.9 \\
\hline 100\% CFs & 83.0 & 56.4 & 51.8 & 12.9 \\
\hline Grains coating with compost amended with (A and N) & 74.8 & 35.7 & 39.0 & 11.1 \\
\hline $\begin{array}{c}\text { Grains coating with compost amended with (A and N) and } \\
\text { 50\% CFs }\end{array}$ & 85.2 & 54.6 & 52.2 & 13.6 \\
\hline $\begin{array}{c}\text { Grains coating with compost amended with (A and N) and } \\
\text { 100\% CFs }\end{array}$ & 86.6 & 50.6 & 50.7 & 13.0 \\
\hline Grains coating with compost & 71.2 & 36.1 & 39.5 & 10.9 \\
\hline Grains coating with compost and 50\% CFs & 75.2 & 45.4 & 44.7 & 12.2 \\
\hline Grains coating with compost and 100\% CFs & 81.4 & 53.9 & 49.7 & 12.1 \\
\hline
\end{tabular}




\begin{tabular}{|c|c|c|c|c|}
\hline Foliar application with (A and N) extract & 72.2 & 34.8 & 43.6 & 11.6 \\
\hline Foliar application with (A and N) extract and 50\% CFs & 82.6 & 54.8 & 51.8 & 13.5 \\
\hline Foliar application with (A and N) extract and 100\% CFs & 81.2 & 53.1 & 53.0 & 13.3 \\
\hline LSD $\leq 0.05$ & 6.0 & 6.2 & 3.7 & 0.9 \\
\hline
\end{tabular}

*Average of ten replicates

At Kurkok station, agronomic traits values were less than those of Al-Sewarah station, yet, the trend of the effects of the tested treatments remained almost consistence across the stations (Table- 8). Treatments of grains coating with compost amended with cyanobacteria, grains coating with compost, and cyanobacteria extract applied as a foliar did not record significant differences in all of the parameters tested in comparison to the control treatment. Exceptions were observed as related to plant height and spike length which increased over control by treatments of grains coating with compost amended with cyanobacteria and foliar application of cyanobacteria extract.

On the other hand, application of 50\% CFs along with compost amended with cyanobacteria or with foliar cyanobacteria extract resulted in similar yield components as that noticed with $100 \%$ CFs.

Table 8-Effects of Anabaena circcinalis and Nostoc commune (A and N) alone and in combination with CFs on some agronomic traits of wheat at Kurkok station

\begin{tabular}{|c|c|c|c|c|}
\hline Treatment* & $\begin{array}{c}\text { Plant } \\
\text { height } \\
\mathrm{cm}\end{array}$ & $\begin{array}{c}\text { Flag } \\
\text { leaf } \\
\text { area } \\
\mathrm{cm}^{2}\end{array}$ & $\begin{array}{c}\text { Chlorophyll } \\
\text { (SPAD } \\
\text { units) }\end{array}$ & $\begin{array}{c}\text { Spike } \\
\text { length } \\
\text { cm }\end{array}$ \\
\hline Control & 60.8 & 29.2 & 30.3 & 8.8 \\
\hline 50\% CFs & 68.2 & 36.3 & 38.9 & 10.8 \\
\hline 100\% CFs & 79.4 & 43.3 & 43.7 & 12.4 \\
\hline Grains coating with compost amended with (A and N) & 70.8 & 30.8 & 34.4 & 11.1 \\
\hline Grains coating with compost amended with (A and N) and & 83.6 & 43.1 & 43.9 & 12.5 \\
\hline Grains coating with compost amended with (A and N) and & 78.8 & 43.4 & 46.1 & 12.2 \\
\hline 100\% CFs & 64.6 & 30.6 & 33.4 & 9.5 \\
\hline Grains coating with compost & 74.6 & 38.3 & 43.1 & 11.1 \\
\hline Grains coating with compost and 50\% CFs & 80.2 & 42.8 & 43.3 & 11.6 \\
\hline Grains coating with compost and 100\% CFs & 72.0 & 33.1 & 35.5 & 11.8 \\
\hline Foliar application with (A and N) extract & 84.0 & 44.5 & 46.0 & 13.3 \\
\hline Foliar application with (A and N) extract and 50\% CFs & 79.0 & 41.5 & 45.4 & 12.5 \\
\hline Loliar application with (A and N) extract and 100\% CFs $\leq 0.05$ & 6 & 4.2 & 4.4 & 1.2 \\
\hline
\end{tabular}

* Average of ten replicates

The increase of the tested growth parameters appeared to be due to complementary effects of cyanobacteria and reduced rate of fertilizers, since the application of $50 \%$ CFs alone resulted in an increase in the tested growth parameters which was less than the increase noticed following the combination of cyanobacteria and 50\% CFs. Cyanobacteria is reported to increase the fertility, productivity and water holding capacity of soil and provide some growth regulators such as auxin, abscisic acid, gibberellins, and vitamin B12. In addition, it has a contribution in increasing the viability of minerals, particularly nitrogen and phosphors that are essentially required for plant growth and development [41].

\section{Conclusions}

Based on the obtained results, it can be concluded that wheat grains coating with compost amended with cyanobacteria or foliar spraying of cyanobacteria in the presence of 50\% chemical fertilizers provide wheat growth and yield similar to that achieved by the label rate of chemical fertilizers. This implicates the importance of such approach in reducing the input of chemical fertilizers into agricultural ecosystems and promoting sustainability.

\section{Acknowledgments}

Thanks to the State Board of Agricultural Researches, Ministry of Agriculture , Baghdad, Iraq for providing the Soil Laboratory facilities and conducting the field study. 


\section{References}

1. Rai, MK. 2006. Handbook of Microbial Bios. Haworth Press,New York.

2. Fawzy, Z.F., El-Shal, Z.S., Yunsheng, L., Zhu, O. and Sawan, O.M. 2012. Response of garlic (Allium Sativum L.) plants to foliar spraying of some bio- stimulants under sandy soil condition. Appl Sci Res. 8: 770-776.

3. Osman, M. E.H., El-Sheekh M.M., El-Naggar, A.H. and Gheda, S.F. 2010. Effect of two species of cyanobacteria as bios on some metabolic activities, growth, and yield of pea plant. Biol. Fertil. Soils. 46: 861-875.

4. Myint, C. C. 1999. Effective Microorganisms (EM) nature farming technology; research and extension activities in Myanmar. Sixth International conference on Kyusei Nature Farming Pretoria, Pretoria, South Africa.

5. Prasanna, R., Joshi, M., Rana, A. and Nain, L. 2010. Modulation of IAA production in cyanobacteria by tryptophan and light. Polish J. Microbiol., 59: 99-105.

6. Rodriguez, A. A., Stella, A. A., Storni, M. M., Zulpa, G. and Zaccaro, M.C. 2006. Effects of cyanobacterial extracellular products and gibberellic acid on salinity tolerance in Oryza sativa $L$. Saline Syst., 2: 7, Doi:101186/ 1746-1448-2-7.

7. Hussain A. and Hasnain. S. 2009. Cytokinin production by some bacteria: Its impact on cell division in cucumber cotyledons. Afr. J. Microbiol. Res., 3: 704-712.

8. Sergeeva, E., Liaimer, A. and Bergman, B. 2002. Evidence of the production of, phytohormone indole-3-acetic acid by cyanobacteria. Plant, 215: 229-238.

9. Amal, Z. H., Soha, S. M. M. and Hamdino, M. I. A. 2010. Influence of different Cyanobacterial Application Methods on Growth and Seed Production of Common Bean under Various Levels of Mineral Nitrogen Fertilization. Horticulture Research Institute, Agriculture Research Center, Giza (Egypt) pp. 349-563.

10. Grzesik, M., Romanowska- Duda, Z. and Kalaji, H. M. 2017. Effectiveness of cyanobacteria and green algae in enhancing the photosynthetic performance and growth of willow (Salix viminalis L.) plants under limited synthetic s application Photosynthetica, 55: 510-521.

11. El-Gamal, M. A. H. 2011. Impact of algal addition to mature compost as affected by different moisture levels. Australian Journal of Basic and Applied Sciences, 5: 729-737.

12. Prasanna, R., Sharma, E., Sharma, P., Kumar, A., Kumar, R., Gupta, V., Pal, R., Shivay, Y. and Nain, L. 2013a. Soil fertility and establishment potential of inoculated cyanobacteria in rice crop grown under non-flooded conditions. Paddy Water Environ. 11: 175-183.

13. Rippka, R. J., Deruelles, J.B., Walerbury, M. H. and Stanier, R.Y. 1979. Generic assignments strain histories and properties of pure cultures of cyanobacteria . J. Gen. Microbial., 111: 1-61.

14. Stanier, R.Y.; Kunisawa, R.; Mandel, M. and Cohen - Bazire, G. 1971. Purification and properties of unicellular blue green algae (order Chroococcales). Bacteriol. Rev., 35: 171 - 205.

15. Pringsheim, E. G. 1949. Pure Culture of Algae, Their Preparation and Maintenance. Cambridge University, Cambridge, UK, xii + 119 pp.

16. Desikachary, T.V. 1959. A monograph on Cyanophyta. Indian Council of Agricultural Research Publication, New Delhi, India.

17. Dumitru, B. and Laura, B. 2012.'Equilibrium and kinetics studies of heavy metal ions biosorption on green algae waste biomass' Journal of Bioresource Technology, 103: 489-493.

18. Svein, A.U. 2006. Microalgae bioprospecting spore swelling and germination as a bioassay for the rapid screening of crude algae extracts for antifungal activity. Degree of cond. Thesis, Institute of Biology, University of Bergen, Norway. $125 \mathrm{P}$.

19. Vonshak, A., Abeliovich, A., Boussiba, S., Arad, S. and Richmond, A. 1982 . Production of Spirulina biomass: effects of environmental factors and population density. Biomass. 2: 175-185.

20. Pise, N. M and Sabale, A. B. 2010. Effect of Seaweed Concentrates on the Growth and Biochemical Constituents of Trigonella Foenum-Graecum L. J. Phytol., 2: 50-56.

21. Sanaa j. B., Rasheed F. T. , Mahdy M. S. 2017. Partial replacement of chemical fertilizers with organic and biofertilizers of Anabaena circcinalis and Oscillatoria lymentica in rice fields. Iraqi Journal of Science, 58: 230-236.

22. Van Reeuwijk, L. P. 1992. Procedures for Soil Analysis. 3d Edn., International Soil Reference and Information Center (ISRIC), Wageningen, The Netherlands, ISBN: 9789066720442. 
23. Rhoads, J. D. and Polemio, M. 1997. Determining cation exchange capacity :Anew procedure for calcareous and gypsiferous soils. Soil sci. Soc. Am. J. 41: 524- 300.

24. Day, P.R. 1965. Particle fractionation and particle size analysis. Black (ed). Methods of soil analysis, Agron. No. 9,Part I: Physical and mineralogical properties. Am. Soc. Agron., Madison, WI, USA.

25. Walkley, A. 1947. A critical examination of a rapid method for determining organic carbon in soils: Effect of variation in digestion conditions and of organic soil constituents. Soil Sci. 63: 251263

26. Jackson, M.L. 1958. Soil chemical analysis. Prentice- wall, Jnc., England Cliffs, N. J., USA..

27. Hesse, P.R. 1971. A Textbook of Soil Chemical Analysis. John Murray. London.

28. Page, A. L. 1982. "Methods of Soil Analysis". Part I. Physical properties and Part II. Chemical and microbiological properties (2nd Ed.). Amer. Soc. Agron. In Soil Sci. Soc. Amer. Inc. Madison Wisconsin, USA, Chapter 12, 199-223.

29. Bremner, J. M. 1965. Total Nitrogen density: In "Methods of soil analysis", pp. 1149- 1176.

30. Olsen, S. R., Cok, C. V., Watanabe, F. S. and Dean, L. A. 1954. Estimation of available phosphorus in soil by sodium bicarbonate. U S. Dept. Agric. Circ., No. 939.USA. Gov. Print. Office, Washington, D. C.

31. Black, G. R. 1965. Methods of soil analysis. Amer. Soc. of Agronomy, Madison, Wisconsin, USA. p:562.

32. Mona, A. A. and Dina, M.G. H. 2014. Effect of cyanobacteria foliar application and different levels of NPK on growth, chemical composition and antioxidant activity of Origanum Majorana L. Scientific J. Flowers \& Ornamental Plants, 1: 171-186.

33. Leaflet of National Program for Wheat Development 2012.

34. Khalid, M. E., El-Hendawy, S., Abdel-Salam1, E., Schmidhalter, U., ur Rehman, S. and Hassan, A. 2016. Foliar application of potassium nitrate affects the growth and photosynthesis in coriander (Coriander sativum L.) plants under salinity Progress in Nutrition Original Article. 18: 63-73.

35. Mzhda J. A. 2017. Investigation of yield, yield component and primary quality characteristics of some bread wheat (Triticum aestivum L.) genotypes. Thesis, Institute of science, University of Bingol, Turkey. $111 \mathrm{P}$.

36. Steel, R. G. D. and Torrie, J. H. 1980. Principles and Procedures of Statistics. A Biometrical Approach. Graw Hill Book Co. Inc., New York, USA.

37. Sanaa, J. B., Jawad, A., Latif, M., Al-Ani, N. K. 2014. Effect of Two Species of Cyanobacteria as Biofertilizers on Characteristics and Yield of Chickpea Plant. Iraqi J. Sci., 55: 685-696.

38. Van, T. D., Ekaterina, Nowak, Y. and Schen, P. M. 2012. Microalgae Isolation and Selection for Prospective Biodiesel Production. ISSN journal Energies, 5: 1835-1849.

39. Hammad, H.M., Ahmad, A., Wajid, A. and Akhter, J. 2011. Maize response to time and rate of nitrogen application. Pak. J. Bot. 43: 1935-1942.

40. Khalil, M., I., Schmidhalter, U., Gutser, R. and Heuwinkel, H. 2011. Comparative efficacy of urea fertilization via supergranules versus prills on nitrogen distribution, yield response and nitrogen use efficiency of spring wheat. Journal of Plant Nutrition, 34: 779-797.

41. Ordog, V. 1999. Beneficial effects of microalgae and cyanobacteria in plant/soil systems, with special regards to their auxin- and cytokinin- like activity. International workshop and training course on microalgal biology and biotechnology. Mosonmagyarovar, Hungary, June: 13-26. 